\title{
Use of biochemical indices for analysis of growth in juvenile two-spotted gobies (Gobiusculus flavescens) of the Baltic Sea
}

\author{
ANDREA FROMMEL and CATRIONA CLEMMESEN \\ Leibniz-Institute for Marine Sciences IFM-GEOMAR, Duesternbrooker Weg 20, D-24105 Kiel, Germany. \\ E-mail: afrommel@ifm-geomar.de
}

\begin{abstract}
SUMMARY: Multiple biochemical measurements were evaluated as an indirect measure of juvenile fish growth rate. Juvenile two-spotted gobies, Gobiusculus flavescens (Fabricius), caught in the Kiel Bight, were incubated in a temperature gradient table at 7 different temperatures ranging from 9 to $22.7^{\circ} \mathrm{C}$ for up to 28 days and sampled weekly. RNA/DNA ratios (RNA/DNA), protein and lipid amounts were measured in whole fish homogenates and compared with calculated weightbased growth rates of the individuals. RNA/DNA values were not significantly correlated with weight-specific growth rates. Lipid- and protein-based growth rates, on the other hand, were highly correlated with weight-specific growth $\left(\mathrm{R}^{2}\right.$ of $0.4-0.5$ ) and lipid-based growth rate explained $45.8 \%$ variability of weight-based growth in a linear growth model. Weightbased growth rates showed a dome-shaped relationship to temperature with a maximum around $16^{\circ} \mathrm{C}$, a trend mirrored in lipid-based growth rates. The results indicate a stage-dependent shift in energy storage and metabolism with a decoupling of RNA/DNA as an index of weight-based growth rate as the juvenile gobies mature and lipids become the main determinant of weight-based growth in these fish.
\end{abstract}

Keywords: Gobiusculus flavescens, juveniles, temperature, growth, RNA/DNA, biochemical indicators.

RESUMEN: UTILIZACIÓN DE ÍNDICES BIOQUÍMICOS PARA ANALIZAR EL CRECIMIENTO EN JUVENILES DEL GOBIO NADADOR (GOBIUSCULUS FLAVESCENS) DEL MAR BÁLTICO. - Múltiples mediciones bioquímicas han sido evaluadas como una medida indirecta de crecimiento en juveniles de peces. Se incubaron juveniles del gobio nadador, Gobiusculus flavescens (Fabricius) del fiordo de Kiel, en una mesa de gradiente de temperatura a 7 diferentes temperaturas en el rango de 9 a $22.7^{\circ} \mathrm{C}$ durante 28 días y se tomaron muestras semanales. Se midieron las proporciones de RNA/DNA y las cantidades de proteínas y lípidos en homogenados de pez entero y se compararon con las tasas de crecimiento en peso calculadas para cada individuo. Se demostró que proporciones de RNA/DNA no estaban correlacionadas de manera significativa con las tasas de crecimiento en peso. Las tasas de crecimiento en lípidos y proteínas, por otro lado, estaban altamente correlacionadas con el crecimiento en peso $\left(\mathrm{R}^{2}\right.$ de $\left.0.4-0.5\right)$ y la tasa de crecimiento en lípidos explicaba el $45.8 \%$ de variabilidad del crecimiento en peso en un modelo linear de crecimiento. Las tasas de crecimiento en peso mostraron una relación asintótica con la temperatura con un máximo cerca de $16^{\circ} \mathrm{C}$, una tendencia reflejada en las tasas de crecimiento basadas en lípidos. Los resultados indican un cambio en almacenamiento de energía dependiente del estado de desarrollo y del metabolismo, con un desaclopamiento del RNA/DNA como un índice del crecimiento en peso a medida que los gobios juveniles se desarrollan, y los lípidos pasan a ser el principal determinante de crecimiento en peso de estos peces.

Palabras clave: Gobiusculus flavescens, juveniles, temperatura, crecimiento, ARN/ADN, indicadores bioquímicos.

\section{INTRODUCTION}

The importance of larval growth and survival for fish stock recruitment has been recognised for a long time (Hjort, 1914), as described by the "growth- mortality hypothesis" that predicts the survival of fish larvae to be directly related to growth, as the predation pressure decreases with increased size of the larvae (Shepherd and Cushing, 1980). However, the role juveniles play in recruitment success has 
only recently been investigated (Campana et al., 1989; Campana, 1996; Baumann et al., 2006). As juveniles represent the bridge between larval and adult fish, and are subject to similar pressures as larvae, it is important to know which factors limit their growth and survival to the next developmental stage.

Many studies have found RNA-DNA ratios (RNA/DNA) to be a good measure of recent growth and condition in larval (Bulow 1970, Buckley 1982, Ferron and Leggett, 1994; Bergeron, 1997; Buckley et al., 1999, Buckley et al., 2006) and some juvenile marine fish (Malloy and Targett, 1994; Kuropat et al., 2002). RNA is sensitive to changes in both feeding regime and temperature, while DNA remains fairly constant in the cell. In times of food limitation, the amount of RNA in the cell is expected to decrease. On the other hand, the concentration of RNA, and thus RNA/ DNA, increases with higher growth rate or protein synthesis. To estimate recent growth in the field, a method has been established in which RNA/DNA values are measured in field-caught young fish and related back to a laboratory calibrated relationship between RNA/DNA and a weight- or size-based growth rate specific to each species and developmental stage (Buckley et al., 2008; Caldarone, 2005). These predictions are important in estimating the recruitment of young fish to the reproducing stock of the population in order to forecast future stock sizes and, for example, to set fishing quotas for commercially exploited species.

A number of studies have also used other biochemical indicators for growth in juvenile fish, such as proteins (Foster et al., 1993; McLaughlin et al., 1994; Peck et al., 2003) and lipids (Wicker and Johnson, 1987). However, few experiments have compared more than two biochemical indicators (nucleic acids, proteins and lipids) in one individual in order to obtain a more complete picture of its recent growth (Weber et al., 2003) and to evaluate the correlations between the different parameters analysed.

The two-spotted goby, Gobiusculus flavescens (Fabricius), was used in this study as a model organism. Although not of commercial importance, gobies play a key role in the food web of the Baltic Sea, being a main prey item of cod, Gadus morhua (Kondratovics, 1997), herring, Clupea harengus, (Lohmeyer and Hempel, 1977), marine mammals (Lick, 1991) and sea birds (Blake, 1983). In turn, gobies are potentially key predators of meiofauna, such as copepods and benthic invertebrates (Cos- tello et al., 1990; Ehrenberg et al., 2005), which makes them an important link between the benthos and larger pelagic predators. A few representatives of this family are highly abundant and are often the dominant species among small fish in the shallow waters of the Baltic Sea, including the common goby, Pomatoschistus microps (Kroeyer), the sand goby, $P$. minutus (Pallas), and the two-spotted goby, Gobiusculus flavescens, (Ehrenberg et al., 2005). Since gobies are found in the shallow coastal waters of the Baltic Sea, they are subject to extreme temperature variations throughout the year. In June 2007 , surface water temperatures varied between $14^{\circ} \mathrm{C}$ and $21^{\circ} \mathrm{C}$ at the Institute for Marine Sciences pier (Kiel, Germany), where the gobies were sampled. In the future, sea surface temperatures are predicted to increase further due to changing climate conditions (BACC, 2008). Therefore, this study was conducted over a wide temperature range above and below that found in the field, to detect the influence of temperature on growth of these gobies.

The aim of this study was to analyze biochemicalbased indicators responsible for growth, namely nucleic acids, proteins and lipids in juvenile two-spotted gobies of the Baltic Sea and to determine how these growth indicators are influenced by temperature.

\section{MATERIAL AND METHODS}

\section{Sampling and experimental procedure}

Approximately 600 juvenile two-spotted gobies (13-18 mm in total length (TL)) were caught using a large dip net off the IFM-GEOMAR pier in Kiel, Germany $\left(54^{\circ} 19^{\prime} 78 \mathrm{~N}, 10^{\circ} 08^{\prime} 96 \mathrm{E}\right)$ in late June 2007 , at average ambient temperatures around $17-18^{\circ} \mathrm{C}$. Following catch, the fish were acclimated to laboratory conditions for one week in holding tanks (120 L) at $18^{\circ} \mathrm{C}$. Subsequently, they were distributed in groups of 12 fish per beaker into $800 \mathrm{ml}$ beakers in a temperature gradient table (holding 42 beakers) after the design by Thomas et al. (1963) and modified by Petereit (2004), allowing them to acclimate for $1 \mathrm{~h}$ per 1 degree centigrade change. The total lengths of the fish transferred to the beakers were not determined at the start of the experiment, as the fish would not have survived the procedure of length measurements unharmed. Therefore the starting length range is based on a subsample of 25 
fish. The beakers contained filtered $(1 \mu \mathrm{m})$ and UV sterilised Baltic seawater with a salinity of 14 and a temperature gradient of $22.7^{\circ} \mathrm{C}$ to $9^{\circ} \mathrm{C}$ in 7 different temperatures $\left(9^{\circ} \mathrm{C}, 11.7^{\circ} \mathrm{C}, 13.9^{\circ} \mathrm{C}, 16.3^{\circ} \mathrm{C}\right.$, $18.5^{\circ} \mathrm{C}, 20.6^{\circ} \mathrm{C}$ and $22.7^{\circ} \mathrm{C}$ ) with six beakers per temperature. The light cycle was set to $18 / 6 \mathrm{~h}$ light/ dark corresponding to the natural conditions at that time. Pressurised air was continuously added to each beaker at adjusted flow to ensure oxygen saturation levels. The gobies were fed daily ad libitum with live, enriched Artemia nauplii (Protein Selco Plus and Spari Selco by Ocellaris), reaching an average food density of 4 nauplii/ $\mathrm{ml}$ in each beaker. The fish in three of the beakers at each temperature were additionally fed daily with $120 \mathrm{mg}$ per beaker $(0.15$ $\mathrm{mg} / \mathrm{ml}$ ) of a mixture of chopped blue mussel (Mytilus edulis), saithe (Pollachius virens) and brown shrimp (Crangon crangon). Additionally, three beakers were stocked with 15 unfed gobies each and placed in temperature-constant rooms at $12^{\circ} \mathrm{C}, 18^{\circ} \mathrm{C}$ and $22^{\circ} \mathrm{C}$ as food-deprived controls. Each day, two thirds of the water in each beaker was exchanged via siphoning and waste products and any dead fish were removed. The average mortality over the entire experimental period was calculated in percentage for each temperature in the gradient table ( 6 beakers per temperature).

After an initial sample of 25 gobies on the first day of the experiment, random samples of 2-3 gobies per beaker were taken every 7 days for 4 weeks in the mornings before feeding by catching them with a small hand net. Half of the gobies in the fooddeprived control group were sampled after the first week and the remainder after the second week. The sampled gobies were shock-frozen with liquid nitrogen and stored in $1.5 \mathrm{ml}$ Eppendorf caps at $-80^{\circ} \mathrm{C}$ until further analysis.

The frozen gobies were measured for their total length (TL; $\mathrm{mm} \pm 0.1)$. Later, they were freezedried for 16 hours (Christ Alpha 1-4 freeze-dryer) at $-51^{\circ} \mathrm{C}$ and reweighed for their dry weight (DW; mg \pm 0.0001 , Sartorius SC 2 microbalance; $\pm 0.1 \mu \mathrm{g}$ ). After freeze-drying biochemical analyses of lipids, RNA/DNA and protein were performed on whole fish.

\section{Biochemical analyses}

Lipid determination: The total lipid content (L) of the gobies was determined gravimetrically following a modified version of the method of Folch et al. (1957). Lipids were extracted with $800 \mu \mathrm{l}$ of 2:1 (v/v) dichloromethane:methanol at $-80^{\circ} \mathrm{C}$ for 52 $\mathrm{h}$ and remaining water was removed with $200 \mu \mathrm{l}$ of $0.88 \%$ potassium chloride (KCL). The amount of lipids in each individual fish was determined by the dry weight loss before and after lipid extraction.

\section{RNA and DNA determination}

Measurements of RNA and DNA were made using the fluorometric method described by Clemmesen (1993) and modified by Belchier et al. (2004) with slight adjustments. Each whole freezedried and de-fatted fish was homogenised in 1600 $\mu 1$ Tris-EDTA (TE) -buffer. This is the first study to report RNA/DNA and lipid values from the same individuals. Preliminary tests showed that nucleic acids were not affected by the process of lipid extraction prior to homogenisation (Malzahn et al., in prep.). A volume of $200 \mu \mathrm{l}$ of the homogenate was removed for protein analysis. The remaining homogenate was combined with 200 $\mu l$ concentrated TE-SDS (sodiumdodecyl sulfate) -buffer with $0.08 \%$ SDS (reaching a final concentration of $0.01 \%$ TE-SDS) and the supernatant was diluted 1:10 with $0.01 \%$ TE-SDS buffer. Ethidium bromide (EB) was used as a specific nucleic acid fluorescent dye for both RNA and DNA and the total fluorescence was measured (Fluoroskan Ascent, LabSystems). RNAse was then used to digest all RNA enzymatically after which the fluorescence of the DNA was determined. Fluorescence was computed to $\mu \mathrm{g}$ nucleic acid via a calibration curve $\left(\mathrm{R}^{2}=0.99\right)$. The amounts of DNA were back-calculated from RNA amounts after Le Pecq and Paoletti (1966) and then standardised after Caldarone et al. (2006).

\section{Protein determination}

Total protein content $(\mathrm{P})$ was determined after the method described by Bradford (1976), using QuickStart ${ }^{\mathrm{TM}}$ Bradford Dye Reagent, 1x from BioRad. Following a modified version of the standard assay for microplates (BioRad), $5 \mu l$ of homogenate was combined with $45 \mu \mathrm{l}$ of TE buffer and $250 \mu \mathrm{l}$ of dye reagent in a UV microtiter plate and the absorption was measured (Multiskan Spectrum, Thermo). A calibration curve $\left(R^{2}=0.99\right)$ was generated using bovine serum albumin from BioRad as a standard at 5 different concentrations. 


\section{Growth determinations}

Instantaneous growth rates, individual approach

Dry weight, lipid and protein content all showed an exponential increase over time, so growth was determined by calculating instantaneous growth rates (Gi) for all three variables based on the following formula:

$$
G i D W=\frac{\ln D W_{f}-\ln D W_{s}}{t_{f}-t_{s}}
$$

where $\mathrm{DW}_{\mathrm{f}}=$ dry weight final (or lipid weight final $\left[\mathrm{L}_{\mathrm{f}}\right]$, or protein weight final $\left[\mathrm{P}_{\mathrm{f}}\right]$ ), $\mathrm{DW}=\mathrm{s}=$ dry weight start (or lipid weight start $\left[\mathrm{L}_{\mathrm{s}}\right]$ or protein weight start $\left.\left[\mathrm{P}_{\mathrm{s}}\right]\right)$ and $\left(\mathrm{t}_{\mathrm{f}}-\mathrm{t}_{\mathrm{s}}\right)=$ time interval between measurements. The Gi was calculated over 7 days. Means (n =6-10) of all individuals within the same treatment were taken as starting values while final values were individual values of the same treatment after 7 days. To calculate the Gi for gobies sampled in the first week, the average of the initial sample $(n=25)$ was used as initial weight.

\section{Average growth coefficients, population approach}

$\mathrm{Gi}$ is calculated by relating individual data points to a previous average and therefore can lead to high variability if the starting population is not homogeneous. To reduce variability, average growth coefficients were computed. This was done by plotting average $(\mathrm{n}=13-19) \mathrm{DW}, \mathrm{L}$ and $\mathrm{P}$ over time (days) for fed fish at each temperature treatment and fitting an exponential growth curve. The growth coefficients of each curve were then plotted over temperature to yield a temperature-dependent growth curve.

\section{Statistical analysis}

The data were statistically analysed with SAS software (SAS Institute, 2001). Least-squares linear regression analyses were used to 1) determine relationships among size, growth rates, lipid content, protein content, RNA/DNA and temperature, 2) determine interactions between variables, and 3) analyze for trends in residuals. To examine differences between weeks and food/no food in the data, SAS ANOVA (analysis of variance) were performed after testing for normality using a Shapiro-Wilks test $(\mathrm{p}>0.05)$ and homogeneity of variance using Levene's test $(\mathrm{p}<0.05)$. The level of significance was set to 0.05 .

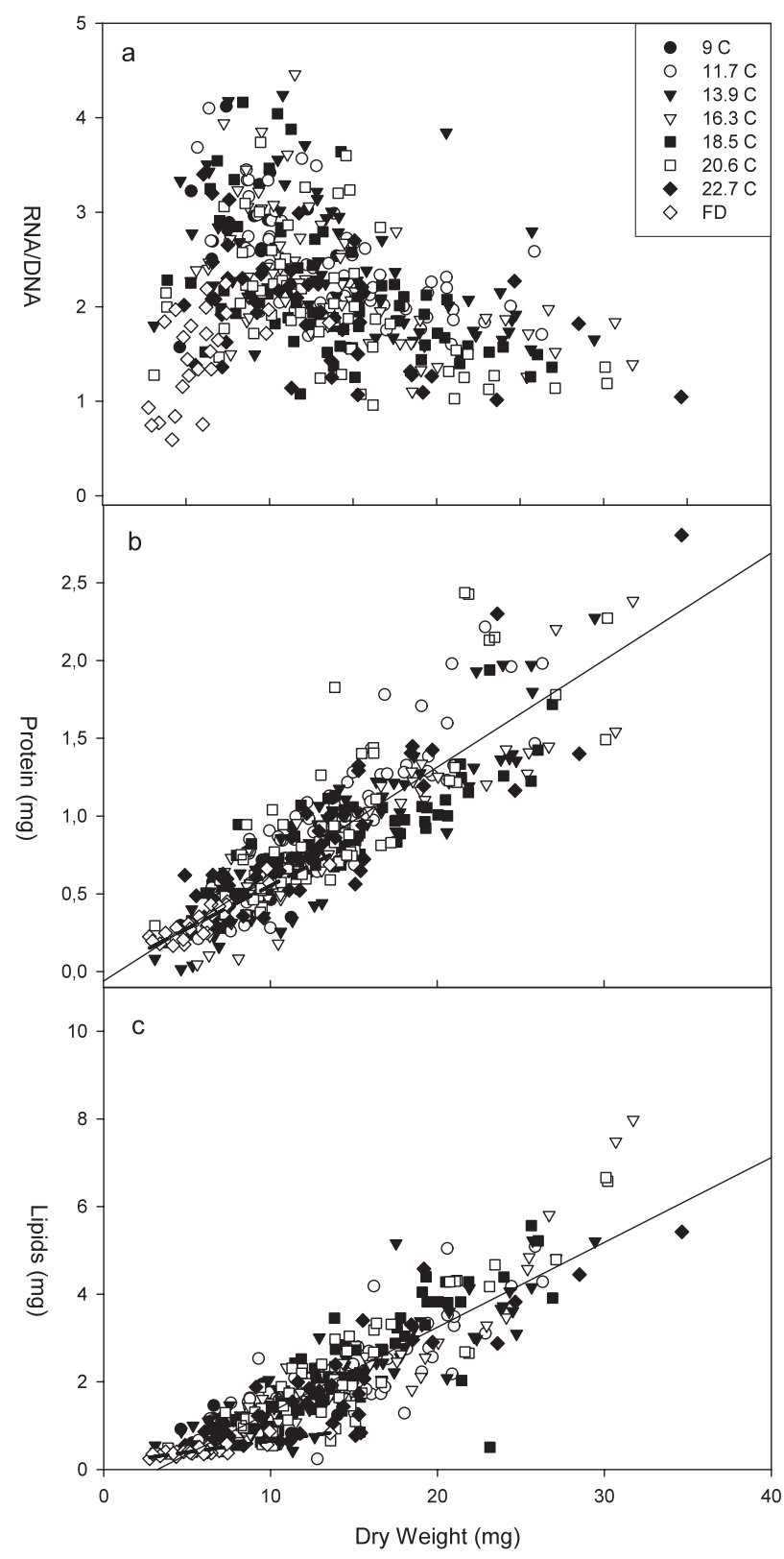

FIG. 1. - Relationship between dry weight and (a) RNA/DNA (b) proteins and (c) lipids for fed fish at 7 different temperatures (overall regression: thin solid line), and food-deprived fish (FD) (regression: dashed thicker line). Regression coefficients for pooled temperatures are given in Table 1.

\section{RESULTS}

No significant difference (ANOVAS $\mathrm{p}>0.15$ ) between the two food treatments (Artemia only and Artemia plus mix of chopped saithe, brown shrimp and mussel) were found for any parameters examined. Therefore, the food treatments were pooled to 6 beakers per temperature for all subsequent analysis. 
TABLE 1. - Parameter estimates for regression models $\left(\mathrm{f}=\mathrm{y} 0+\mathrm{a}^{*} \mathrm{x}\right)$ of dry weight $(\mathrm{mg}, \mathrm{DW})$ for fed fish, coefficient of determination $\left(\mathrm{R}^{2}\right)$, degrees of freedom (DF) and p value. Independent variables: lipid ( L), protein(P), RNA and DNA contents.

\begin{tabular}{|c|c|c|c|c|c|}
\hline Independent variable & y0 & $\mathrm{a}$ & $\mathrm{R}^{2}$ & $\mathrm{DF}$ & $\mathrm{p}$ \\
\hline $\mathrm{L}(\mathrm{mg})$ & -0.6218 & 0.1935 & 0.764 & $\mathrm{~F} 1,380=1229.74$ & $<0.0001$ \\
\hline $\mathrm{P}(\mathrm{mg})$ & -0.0609 & 0.0688 & 0.746 & $\mathrm{~F} 1,379=1107.91$ & $<0.0001$ \\
\hline RNA $(\mu \mathrm{g})$ & 0.0445 & 0.003 & 0.436 & $\mathrm{~F} 1,373=288.69$ & $<0.0001$ \\
\hline DNA $(\mu g)$ & 0.0062 & 0.0033 & 0.690 & $\mathrm{~F} 1,373=832.46$ & $<0.0001$ \\
\hline
\end{tabular}

\section{Mortality}

The mortality displayed an inverse dome-shaped trend over temperature, with most mortalities occurring at the temperature extremes of $9^{\circ} \mathrm{C}(73 \%$ mortality) and $20.8^{\circ} \mathrm{C}(32 \%$ mortality), and the lowest average mortality occurring between $11.7^{\circ} \mathrm{C}$ and $18.7^{\circ} \mathrm{C}$ ( $6 \%$ mortality). The percent mortality in the food-deprived control groups was at least 5 times higher than that in the fed groups at all temperatures examined.

\section{Biochemical indicators}

There was no interaction between dry weight (DW) and temperature, and regressing RNA, DNA, protein and lipid content on temperature with DW as a covariate indicated that all variables varied with DW but not with temperature. The analysis of the residuals for these regressions on growth rate showed no trend.

RNA/DNA values measured in the whole fish were highly variable, ranging from 0.6 to 4.9 . While RNA/DNA in the smaller fed fish (3-10 mg DW) showed a large range of values from 1 to 4.9 , the range was smaller and maximum values lower in the larger fish (27-35 mg DW) with RNA/DNA values from 1.2 to 1.8 (Fig. 1a). The food-deprived control group (3-14 mg DW) had lower RNA/DNA values ranging between 0.6 and 2.3, overlapping with the fed individuals. There was no correlation between RNA/DNA and the size of the fish. Mean RNA/DNA ratios differed significantly (ANOVA, $\mathrm{p}<0.0001$ ) between fed and non-fed fish at the extreme temperatures examined $\left(12^{\circ} \mathrm{C}\right.$ and $\left.22^{\circ} \mathrm{C}\right)$ after 7 days in the experiment, but not at the mid-temperatures (Fig. 2). Fed fish at the lowest temperature $\left(12^{\circ} \mathrm{C}\right)$ had the highest mean RNA/DNA ratio, while the non-fed fish at the highest temperature had the lowest mean RNA/DNA ratio. This was also reflected in the survival, with only food-deprived fish at $18^{\circ} \mathrm{C}$ surviving another week.

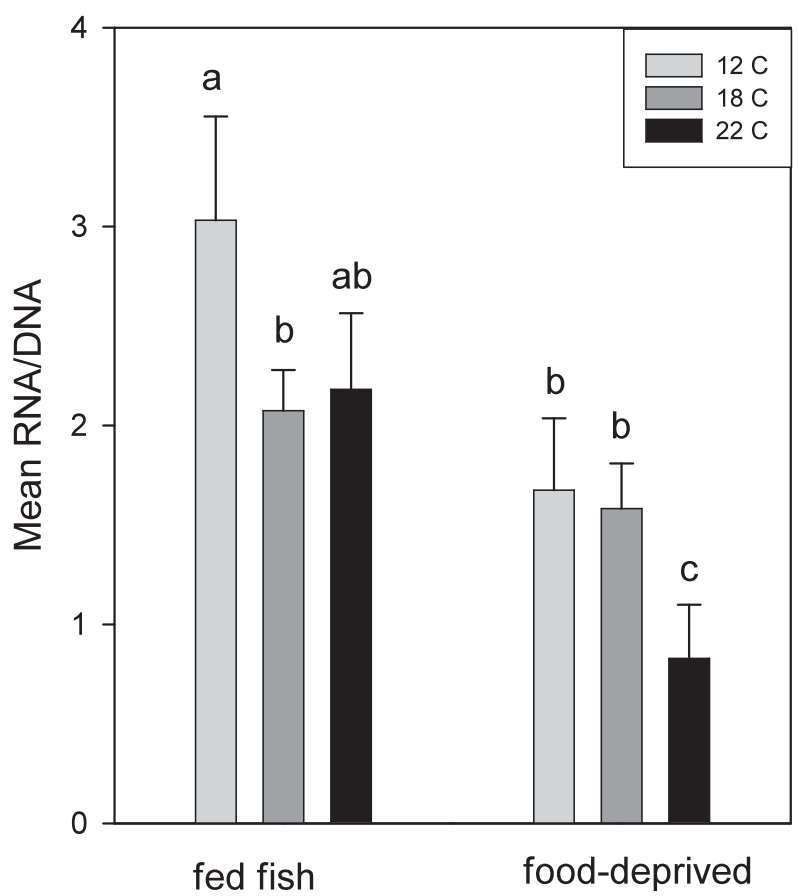

FIG. 2. - Mean RNA/DNA with standard deviation of fed and fooddeprived fish at 3 different temperatures after 7 days. Letters denote significant differences as determined by ANOVA.

Total protein weight was positively correlated with DW $(\mathrm{p}<0.0001)$ and showed a similar positive linear trend to that of lipids (Fig. 1b, Table 1). Fed fish did not have significantly more protein on a DW basis than the food-deprived control group between 0 and $10 \mathrm{mg} \mathrm{DW}$ ( $\mathrm{p}=0.1232$ ).

The total lipid weight of each fish plotted with respect to total DW yielded a linear positive trend (Fig. 1c). The food-deprived control group had a much lower slope than the fed fish with significantly reduced specific lipid contents $(\mathrm{p}<0.0001)$.

While DNA weight correlated linearly with dry weight (Table 1, figure not shown), RNA weight was related to DW linearly only up to a DW of about $15 \mathrm{mg}$, after which the data points scatter strongly with slight decreasing trend (overall fitted regression presented in Table 1, figure not shown). This relationship is reflected in the RNA/DNA relation to DW as presented in Figure 1a. 


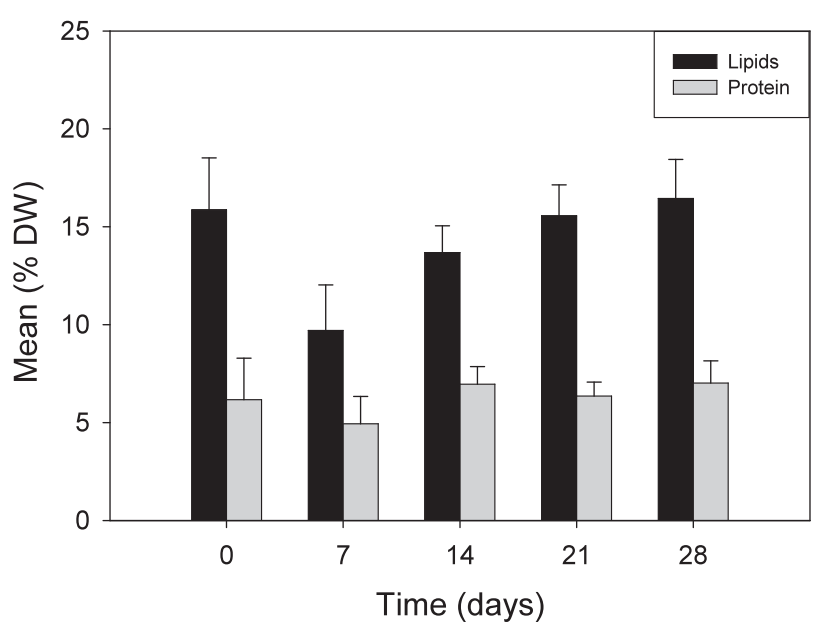

FIG. 3. - Mean relative lipid content (\% DW) (black bars) and protein content (\% DW) (grey bars) along with standard deviation over sampling interval.

\section{Relative composition}

The relative composition of lipids and proteins were not correlated with temperature. However, time was a significant factor in the composition. Relative lipid content ( $\mathrm{Lr}$ ) calculated as percentage of lipids in DW varied significantly with experimental days (ANOVA, $\mathrm{p}<0.0001$ ), being lower in week one (7 days) than in the starting group but increasing steadily from then until the termination of the experiment (Fig. 3). Relative protein content (Pr), on the other hand, remained relatively constant throughout the experiment. While the Lr of the food-deprived control groups was significantly lower than that of both the start group and their fed counterparts (ANOVA, $\mathrm{p}<0.0001)$, the $\operatorname{Pr}$ was not significantly different (ANOVA, $\mathrm{p}>0.05$ ). The food-deprived control groups did not differ significantly in temperature (ANOVA, $\mathrm{p}>0.05$ ) or time for either Pr or Lr.

\section{Relation between growth rates and biochemical indicators}

Regressing GiDW over RNA/DNA yielded no significant relation over 7 days (Fig. 4a). Adding temperature as a factor did not improve the explanatory power of the model. Additionally, the RNA/ DNA values of the food-deprived fish were not significantly different from the well-fed fish.

There was no interaction between GiDW and temperature. Plotting the residuals against temperature showed no trend. Regressing lipid content, protein content, and RNA and DNA content on GiDW with temperature as a covariate showed that there was no
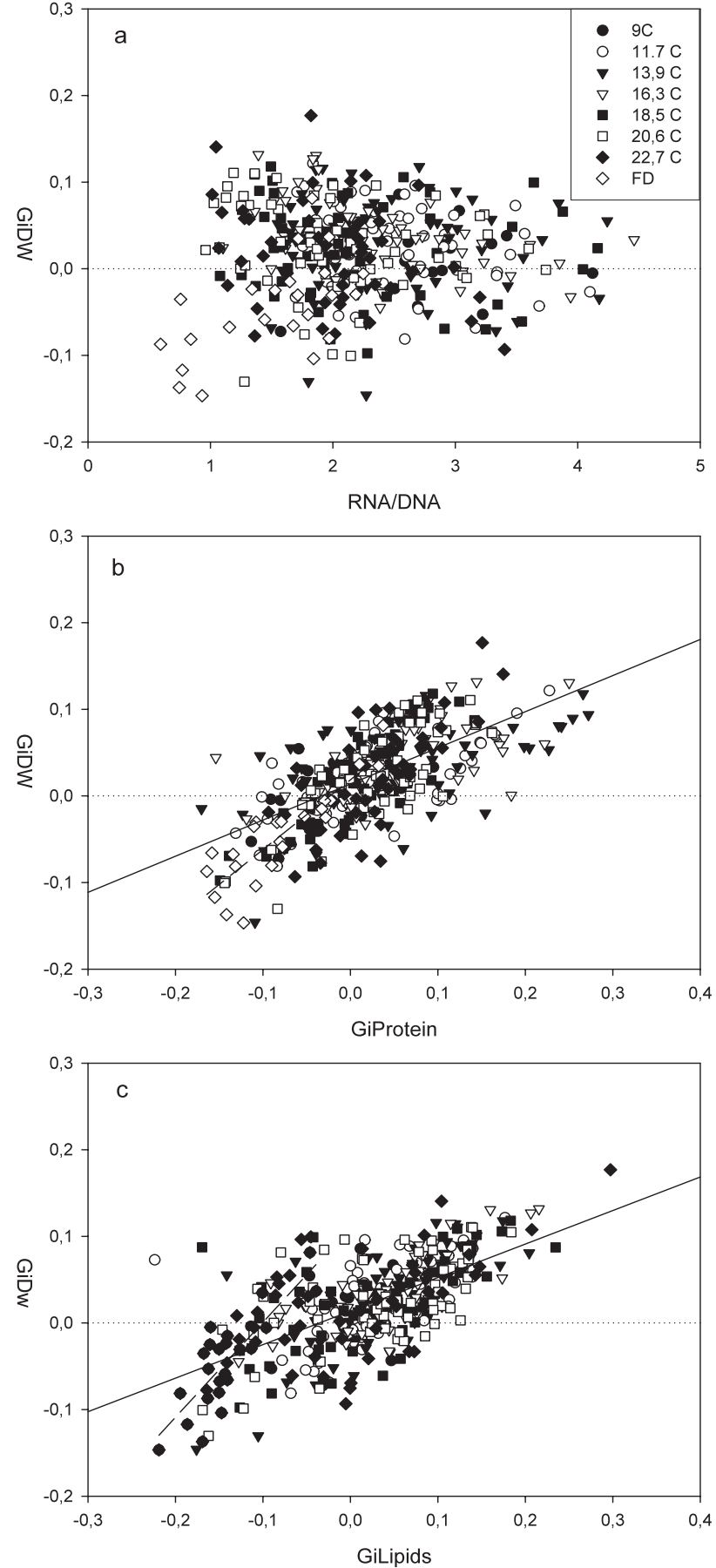

FIG. 4. - Instantaneous growth of dry weight (GiDW) versus (a) RNA/DNA, (b) change in protein (GiP) and (c) change in lipids (GiL) over 7 days for fed fish at 7 different temperatures and the food-deprived control group (FD). Regression curves for pooled temperatures are given in Table 2.

trend with temperature or GiDW. Residuals from the regressions for all of the variables examined showed no trend when plotted against temperature only when analyzed in regards to DW.

RNA/protein did not correlate with either GiDW nor GiP. Furthermore, there was no correlation be- 
TABLE 2. - Parameter estimates for regression models $\left(\mathrm{f}=\mathrm{y} 0+\mathrm{a}^{*} \mathrm{x}\right)$ of GiDW for time intervals of 7 days, $\mathrm{R}^{2}$, degrees of freedom (DF) and $\mathrm{p}$ value. Independent variables: GiP and GiL for fed fish, GiL for food-deprived fish (GiL FD).

\begin{tabular}{lccccc}
\hline Independent variable (mg/day) & y0 & $\mathrm{a}$ & $\mathrm{R}^{2}$ & $\mathrm{DF}$ & $\mathrm{p}$ \\
\hline GiP & 0.0163 & 0.3616 & 0.397 & $\mathrm{~F} 1,360=265.12$ & $<0.0001$ \\
GiL & 0.0137 & 0.3871 & 0.379 & $\mathrm{~F} 1,380=233.01$ & $<0.0001$ \\
GiL FD & 0.0134 & 0.4072 & 0.682 & F1,22=44.94 & $<0.0001$ \\
\hline
\end{tabular}

TABLE 3. - Model of instantaneous growth rate in dry weight (GiDW) as a function of instantaneous growth rate in lipids (GiL), instantaneous growth rate in protein (GiP) and RNA/DNA for fed fish.

\begin{tabular}{|c|c|c|c|c|c|c|c|}
\hline No. & y & $\mathrm{x}_{1}$ & $\mathrm{x}_{2}$ & $\mathrm{x}_{3}$ & equation & $\mathrm{R}^{2}$ & $\mathrm{n}$ \\
\hline 1 & GiDW & GiL & & & $\mathrm{y}=0.0136+0.3960 \mathrm{x}_{1}$ & 0.458 & 405 \\
\hline 2 & GiDW & GiL & GiP & & $\mathrm{y}=0.0115+0.2534 \mathrm{x}_{1}+0.2417 \mathrm{x}_{2}$ & 0.558 & 405 \\
\hline 3 & GiDW & GiL & $\mathrm{GiP}$ & RNA/DNA & $\mathrm{y}=0.0217+0.2457 \mathrm{x}_{1}+0.2514 \mathrm{x}_{2}^{2}-0.0047 \mathrm{x}_{3}$ & 0.561 & 405 \\
\hline
\end{tabular}

tween RNA/DNA and GiP. The residuals of these regressions plotted over temperature showed no trend. RNA concentration on a dry weight basis vs. GiDW showed no trend.

\section{Comparison of instantaneous growth rates}

The increase in protein per day (GiP) was significantly correlated with all changes in DW over the experimental period $(\mathrm{p}<0.0001)$. When the GiDW was plotted over 7 days versus GiP a positive linear trend appeared, with $\mathrm{P}$ explaining $41 \%$ variability in DW growth rate (Fig. 4b, Table 2). Temperature was not significant in the relationship between GiP and GiDW. The food-deprived gobies exhibited mainly negative GiP, but were not significantly different.

The increase in lipids per day (GiL) calculated over 7 days was positively correlated with the instantaneous growth rate GiDW, with an explained variability of $38 \%$ (Fig. 4c, Table 2). Temperature was not significant in the relationship between GiL and GiDW. The food-deprived fish had significantly lower GiDW per GiL over a 7-day interval, displaying negative Gi in both DW and L (68\% explained variability) (Fig. 4c, Table 2).

\section{Growth mode}

The instantaneous growth rates per day (GiDW, GiL and GiP) over the last 7 days of the experiment were calculated for each individual juvenile goby and a stepwise multiple linear regression analysis was run (Table 3 ) to determine which mode of growth was responsible for the change in GiDW. The first parameter to go into the model was GiL, which explained $45.8 \%$ variability of growth rate. The second parameter, GiP, increased the explanatory power to $55.8 \%$. By adding the parameter RNA/ DNA, $56.1 \%$ of growth rate could be explained by the model. Although the RNA/DNA explained a negligible amount of variability, it was significant $(\mathrm{p}=0.0102)$. Temperature was not significant in the regression model. Plotting the residuals of the regression by temperature or DW showed no trend. Only fed fish were used in the model.

\section{Growth coefficients, effect of temperature}

As the calculated individual Gi's did not yield temperature-dependent trends, growth coefficients from the population approach were determined by plotting DW over time for each temperature treatment and fitting exponential growth curves to the relationship (Fig. 5, Table 4). These growth coefficients varied with temperature, displaying a domeshaped relationship with a peak between $16^{\circ} \mathrm{C}$ and $18^{\circ} \mathrm{C}$ (Fig. 6). The $9^{\circ} \mathrm{C}$ group was not included in this analysis as all fish had been sampled or had died by the third week.

Temperature also influenced the amount of lipids in the experimental fish. As seen for DW, lipid was positively correlated with time, displaying different exponential relationships depending on temperature (Fig. 5, Table 4). Lipid growth coefficients plotted over temperature resulted in a dome-shaped curve with a temperature optimum between $16^{\circ} \mathrm{C}$ and $18^{\circ} \mathrm{C}$, corresponding to the temperature maximum in dry weight growth coefficient (Fig. 6, Table 4). Again, the $9^{\circ} \mathrm{C}$ group was not included because all fish had been sampled or had died by the third week. 


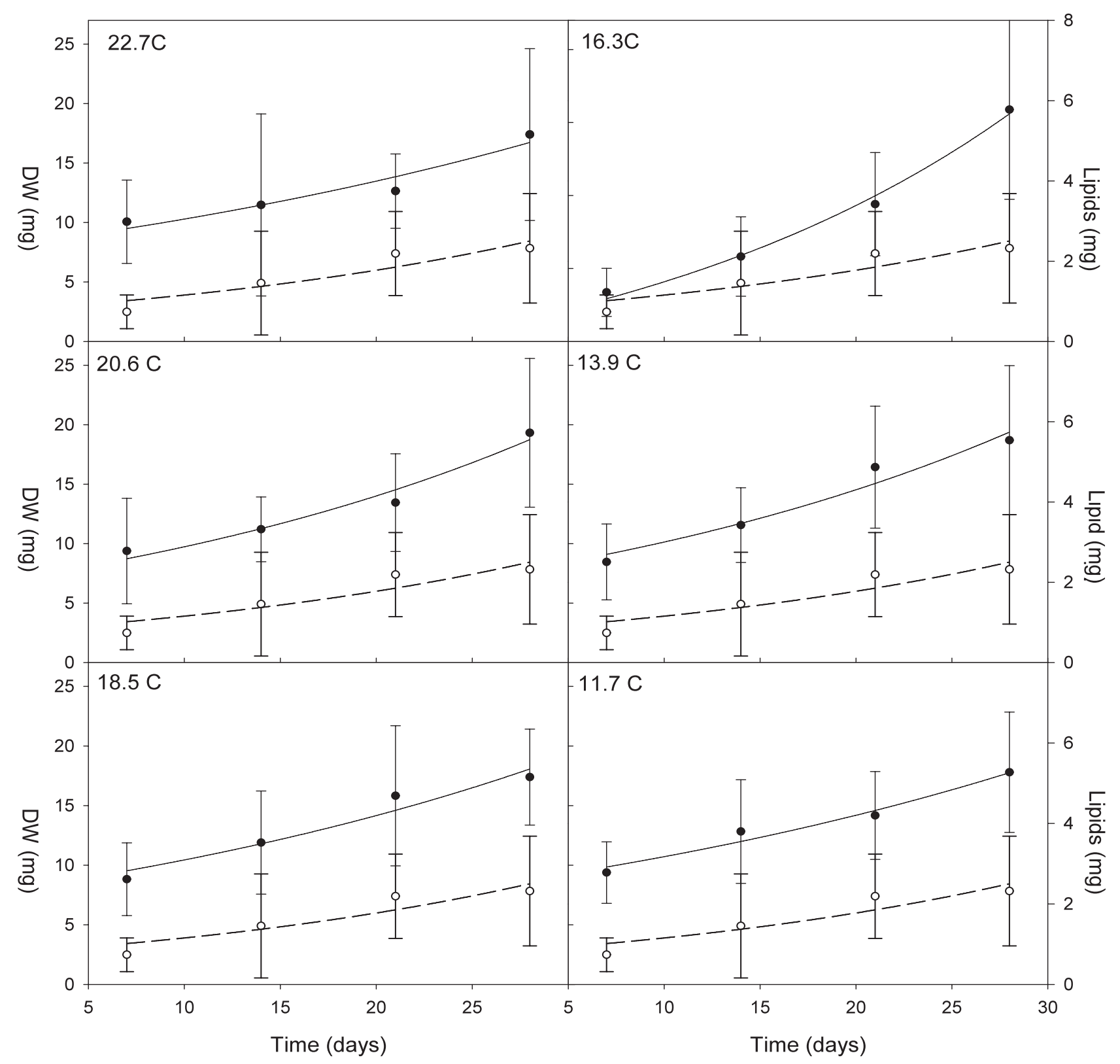

FIG. 5. - Dry weight (DW) (black circles, solid line) and lipids (open circles, dashed line) vs. time for 6 different temperatures, $22.7^{\circ} \mathrm{C}, 20.6^{\circ} \mathrm{C}$, $18.5^{\circ} \mathrm{C}, 16.3^{\circ} \mathrm{C}, 13.9^{\circ} \mathrm{C}$ and $11.7^{\circ} \mathrm{C}$. Error bars indicate standard deviation from the average. Functions along with statistics are listed in Table 4.

Although the observed trends are not significant (Table 4), temperatures $12^{\circ} \mathrm{C}$ and $16^{\circ} \mathrm{C}$, and $16^{\circ} \mathrm{C}$ and $23^{\circ} \mathrm{C}$ do differ significantly from each other in either DW or lipid growth.

\section{DISCUSSION}

\section{RNA/DNA as an indicator of growth}

The initial aim of this study was to test the use of RNA/DNA as an indicator of growth in juvenile gobies and to create a temperature-dependent model for application in the field.

Many studies have found a direct linear relationship between RNA-DNA ratios, temperature and weight-specific growth rates in several species of larvae held under laboratory conditions (Buckley et al., 1984; Buckley et al., 2008, Caldarone, 2005) and in juveniles (McLaughlin et al., 1994; Malloy and Targett, 1994; Peck et al. 2003), and established multiple linear regression models that could be used to determine recent growth in the field. Additional to RNA/DNA values, RNA concentration in muscle 
TABLE 4. - Parameter estimates, $\mathrm{R}^{2}$, degrees of freedom (DF) and $\mathrm{p}$ value for exponential growth $\left[\mathrm{f}=\mathrm{a}^{*} \exp \left(\mathrm{b}^{*} \mathrm{x}\right)\right]$ in dry weight (DW) and lipids (L) over 6 different temperatures (T) (Fig. 5), along with the overall dome-shaped relationship over all temperatures from Fig. 6.

\begin{tabular}{|c|c|c|c|c|c|c|}
\hline Independent variable & $\mathrm{T}\left[{ }^{\circ} \mathrm{C}\right]$ & $\mathrm{a}$ & $\mathrm{b}$ & $\mathrm{R}^{2}$ & $\mathrm{DF}$ & $\mathrm{p}$ \\
\hline DW & 22.7 & 7.855 & 0.027 & 0.926 & $\mathrm{~F} 1,3=26.17$ & 0.038 \\
\hline DW & 20.6 & 6.763 & 0.036 & 0.966 & $\mathrm{~F} 1,3=56.04$ & 0.017 \\
\hline DW & 18.5 & 7.701 & 0.031 & 0.945 & $\mathrm{~F} 1,3=34.27$ & 0.028 \\
\hline DW & 16.5 & 5.769 & 0.045 & 0.993 & $\mathrm{~F} 1,3=289.24$ & 0.003 \\
\hline DW & 13.9 & 7.068 & 0.036 & 0.957 & $\mathrm{~F} 1,3=44.52$ & 0.022 \\
\hline DW & 11.7 & 8.096 & 0.028 & 0.970 & $\mathrm{~F} 1,3=64.41$ & 0.015 \\
\hline DW & all & 0.013 & 0.000 & 0.548 & $\mathrm{~F} 1,3=1.82$ & 0.304 \\
\hline Lipids & 22.7 & 0.753 & 0.043 & 0.857 & $\mathrm{~F} 1,3=11.97$ & 0.074 \\
\hline Lipids & 20.6 & 0.579 & 0.064 & 0.975 & $\mathrm{~F} 1,3=76.36$ & 0.013 \\
\hline Lipids & 18.5 & 0.642 & 0.059 & 0.952 & $\mathrm{~F} 1,3=40.01$ & 0.024 \\
\hline Lipids & 16.5 & 0.480 & 0.073 & 0.984 & $\mathrm{~F} 1,3=121.98$ & 0.008 \\
\hline Lipids & 13.9 & 0.784 & 0.050 & 0.961 & $\mathrm{~F} 1,3=49.81$ & 0.020 \\
\hline Lipids & 11.7 & 0.906 & 0.043 & 0.905 & $\mathrm{~F} 1,3=19.14$ & 0.049 \\
\hline Lipids & all & 0.028 & -0.001 & 0.758 & $\mathrm{~F} 1,3=4.70$ & 0.119 \\
\hline
\end{tabular}

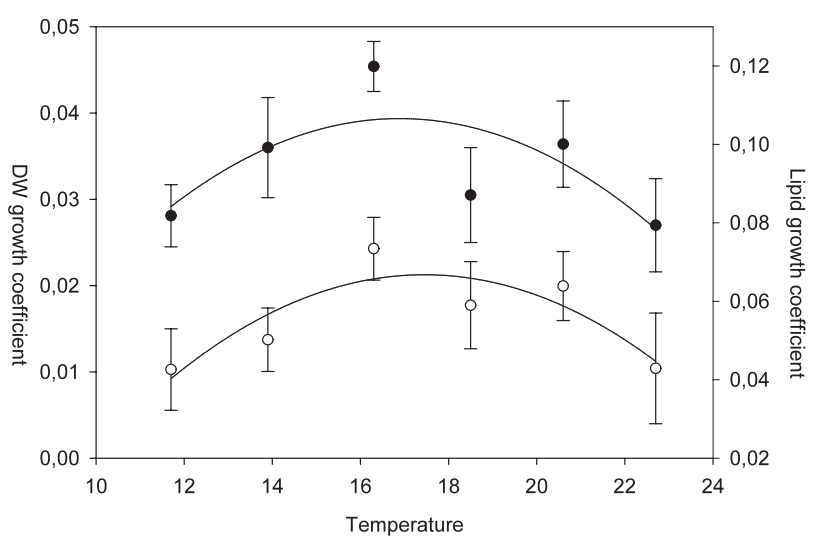

FIG. 6. - Growth coefficients obtained from dry weight (DW) and lipids (L) vs. experimental days (Fig. 4) plotted over temperature $\left({ }^{\circ} \mathrm{C}\right)$. Error bars indicate slope errors obtained in Fig. 4. Functions: $\mathrm{f}(\mathrm{DW}, \mathrm{T})=-0,069(+/-0,058)+0,0128(+/-0,007) *$ growth coefficient $(\mathrm{DW}) ;\left(\mathrm{DF}_{13}=1.82 ; \mathrm{p}<0,5\right) \mathrm{f}(\mathrm{L}, \mathrm{T})=-0,177(+/-0,076)+0,028(+/-$ $0,0091)^{*}$ growth coefficient $(\mathrm{L})-0,001 *$ growth coefficient $(\mathrm{L})^{\wedge} 2$ $\left(\mathrm{DF}_{1,3}=4,70 ; \mathrm{p}<0,5\right)$

tissue has been found to be positively related to instantaneous growth rates in marine fish (Kuropat et al. 2002; Mathers et al., 1992; Foster et al., 1993; Carter et al., 1998).

Since RNA/DNA reflects protein biosynthesis capacity, the lack of correlation between weightbased growth in our fish and RNA/DNA could be explained by the fact that it was lipid deposition, and not protein, which was responsible for the observed increase in dry mass. A multiple linear regression model including instantaneous dry weight growth rates (GiDW), lipid changes (GiL) and protein changes (GiP), along with a temperature term, confirmed that lipids are indeed the main factor contributing to weight-based growth, while proteins play only a marginal role and temperature did not significantly affect the relation between GiL and GiDW. These results indicate a decoupling of
DW growth rate and RNA/DNA due to the constant level of protein synthesis regardless of weight, developmental stage and condition, while lipid deposition increased at this developmental stage. An explanation for this is a transition in the biochemical composition of the fish during ontogeny and tissue reorganisation. This phenomenon has been observed in leptocephalus larvae in bonefish (Pfeiler and Luna, 1984) and flatfish (Richard et al., 1991). The protein content of fish tends to shift greatly during development. While larvae require a large amount of protein for rapid growth, the protein requirement of a fish decreases as it matures. When a fish reaches sexual maturity, it accumulates a high protein content needed for the formation of reproductive organs. In adult sand gobies, Pomatoschistus minutus, protein content is highest during the peak spawning period of March to May (Sole et al., 2006). As the seasons progress, they tend to switch their metabolism to storing lipids instead of protein in preparation for winter rest. The protein content measured in G. flavescens remained relatively constant over the experimental period and was not significantly affected by temperature. Little research has been conducted on the influence of temperature on protein synthesis of marine fish (Carter and Houlihan, 2001; Katersky and Carter, 2007). In some of these studies temperature was shown to affect the rate of protein synthesis. Sole et al. (2006) found seasonal variations in protein synthesis in $P$. minutus of comparable size to the $G$. flavescens used in this study, with a maximum from March to May and a minimum from August to September. As neither RNA activity nor protein synthesis rates, but only standing stocks of protein and RNA, were measured in this experiment, this 
explanation cannot be tested. Nor did the relative protein content in the present study differ between fed and non-fed gobies. This indicates that the nonfed gobies did not use protein as an energy source in times of food limitation, since protein is not a good source of energy and is only used for metabolic purposes when other sources such as fats are not available. Instead, lipids were used as reflected in the decreased lipid contents in food-deprived gobies.

Groves (1970) already suggested that lipids are the main determinant of a juvenile fish's condition, as they are a function of their nutritional history. Lipids are an important source of energy and are used before protein. Furthermore, lipids-particularly membrane lipids-play an important role in acclimation (Hoar and Randall, 1969). The total lipid content in the food-deprived G. flavescens was markedly lower than that of their fed conspecifics. Other studies have also found the total fat content of the body to be correlated with condition and growth in adult and juvenile fish (Oliver et al., 1979; Keast and Eadie, 1985; Wicker and Johnson, 1987). Lipid stores in muscle tissue or in the liver increase with size and age of fish due to reduced activity level, growth rate and metabolism and are increased prior to gonad maturation in juvenile fish (Hoar and Randall 1969). The range of the relative lipid content $(12-15 \%$ of the dry weight) in G. flavescens lies within the upper range of literature values for other goby species (4-13\% in adult sand gobies, Pomatoschistus minutus, Lissåker et al., 2003) and is comparable to that of other fish species and marine invertebrates (Barnes and Blackstock, 1973).

It has been found that the growth mode of young gobies changes from hyperplasia to hypertrophy as they mature (Frommel, 2008). Most likely the changes in RNA/DNA with increased size were a result of a combination of changes in biochemical composition, tissue reorganisation and behaviour, which lead to changes in the metabolism of the gobies. The lack of a positive correlation between nucleic acids and DW growth rates in juvenile gobies, which conflicts with findings for other juvenile fish species, could be due to the fact that juvenile gobies are much closer to adulthood than slower-growing, longer-lived species. G. flavescens mature within a year, so the juveniles of this species are much older and have stronger developmental constraints coupled with growth than i.e. cod, which become sexually mature after 4-5 years.

\section{Growth rates and temperature}

The slope-derived growth rates showed a domeshaped temperature trend with an optimum around $16^{\circ} \mathrm{C}$. Although this relationship was not significant, it does have important biological implications. While the lowest temperature $\left(9^{\circ} \mathrm{C}\right)$ proved to be lethal after only one week of incubation, there was a temperature optimum around $16^{\circ} \mathrm{C}$, which correlates with the ambient water temperature found in the Kiel Bight when the fish were caught. Clearly, G. flavescens grew best at the temperature they had experienced in the field and had become acclimated to. An asymmetric growth pattern in which growth increases with temperature to a maximum and then sharply decreases at higher temperatures was found in other studies: for example in juvenile wolffish (McCarthy et al., 1999) and in juvenile Atlantic cod and haddock larvae, where Peck et al. (2003) also found a dome-shaped trend with a maximum growth rate at $12^{\circ} \mathrm{C}$.

Similar to dry weight growth rates, lipid growth rate in juvenile two-spotted gobies were (not significantly) related to temperature with a maximum around $16^{\circ} \mathrm{C}$. Furthermore, instantaneous lipid growth rates (Gi lipids) were (significantly) positively related to instantaneous dry weight growth rates (Gi dw). This indicates that the condition of $G$. flavescens was best at $16^{\circ} \mathrm{C}$ and that its weight-based growth is most likely a result of lipid deposition.

The lack of temperature sensitivity in growth in these fish suggests that they will not be greatly affected by global climate change. As gobies live in the shallow littoral, they are subject to wide fluctuations in temperature throughout the year and are thus rather robust to changes in water temperature within the range they experience. This family will therefore most likely remain unaffected by the predicted increased seasonal water temperatures.

\section{CONCLUSION}

In juvenile two-spotted gobies, lipids are easily incorporated into the tissue and are readily metabolised in times of food deprivation. Lipids are significantly depleted after only 2 weeks of fooddeprivation. In contrast, DW growth rates, RNA/ DNA and protein concentrations remain largely unchanged. This means that juvenile gobies respond to food deprivation by rapidly using their lipid stores 
in order to sustain growth. Along with food rations, temperature affects growth in juveniles and linear growth patterns for each temperature lead to an overall dome-shaped relationship with a maximum DW growth rate at in situ temperatures at time of catch. This dome-shaped relationship was mirrored by the lipid-based growth rate but not by the protein-based growth rate or RNA/DNA.

It can be concluded that lipids are the most important determinant of the observed increase in dry mass (DM) of juvenile gobies, while RNA/DNA is decoupled from DM at this stage and no longer acts as a good indicator for recent growth based on weight. Therefore, measuring nucleic acid concentrations in field-caught juvenile marine fish may not be useful for estimating DW growth rates for every species or developmental stage. Further research is needed to determine which other species undergo this change in growth mode at this stage and for which species RNA-DNA ratios still remain a direct measure of weight-based growth in juveniles.

\section{ACKNOWLEDGEMENTS}

The authors would like to thank Dr. Christoph Petereit for his help and advice in this experiment. Furthermore, we are grateful to Helgi Mempel for his support in the lab. This study forms part of the DFG Project 1162 "Aquashift", CL 126/3. Finally, we thank the reviewers for their comments, which greatly benefited the manuscript.

\section{REFERENCES}

BACC Author Team. - 2008. Assessment of climate change for the Baltic Sea Basin. Springer.

Barnes, H. and J. Blackstock. - 1973. Estimation of lipids in marine animals and tissues: detailed investigation of the sulphophosphovanillin method for 'total' lipids. J. Exp. Mar. Biol. Ecol., 12: 103-118.

Baumann, H., R.Voss, H.H.Hinrichsen, C. Möllmann, F.W. Köster, A.M. Malzahn and A. Temming. - 2006. Recruitment variability in Baltic Sea sprat (Sprattus sprattus) is tightly coupled to temperature and transport patterns affecting the larval and early juvenile stages. Can. J. Fish. Aquat. Sci., 63: 2191-2201.

Belchier, M., C. Clemmesen, D. Cortes, T. Doan, A. Folkvord, A Garcia, A. Geffen, H. Høie, A. Johannessen, E. Moksness, H. de Pontual, T. Ramirez, D. Schnack, and B. Sveinsbo. - 2004. Recruitment studies: manual on precision and accuracy of tools. ICES Tech. Mar. Environ. Sci., 33: 1-35.

Bergeron, J.P. - 1997. Nucleic acids in ichthyoplankton ecology: a review, with emphasis on recent advances for new perspectives. J. Fish Biol., 51: 284-302.

Blake, B.F. - 1983. A comparative study of the diet of auks killed during an oil incident in the Skagerrak in January 1981. J. Zool., 201: 1-12.

Bradford, M. - 1976. A rapid and sensitive method for the quantiza- tion of microgram quantities of protein utilizing the principle of protein-dye binding. Anal. Biochem., 72: 248-254.

Buckley, L.J. - 1982. Effects of temperature on growth and biochemical composition of larval winter flounder (Pseudopleuronectes americanus). Mar. Ecol. Prog. Ser., 8: 181-186

Buckley, L.J., S.I. Turner, T.A. Halavik, A.S. Smigielski, S.M. Drew and G.C. Laurence. - 1984. Effects of temperature and food availability on growth, survival, and RNA-DNA ratio of larval sand lance (Ammodytes americanus). Mar. Ecol. Prog. Ser., 15: 91-97.

Buckley, L.J., E. Caldarone and T.L. Ong. - 1999. RNA-DNA ratio and other nucleic acid-based indicators for growth and condition of marine fishes. Hydrobiologia, 401: 265-277.

Buckley, L.J., E. Caldarone, R.G. Lough and J.M. St. Onge-Burns. - 2006. Ontogenetic and seasonal trends in recent growth rates of Atlantic cod and haddock larvae on Georges Bank: effects of photoperiod and temperature. Mar. Ecol. Prog. Ser., 325: 205-226.

Buckley, L.J., E.M. Caldarone and C. Clemmesen. - 2008. Multispecies larval fish growth model based on temperature and fluorometrically derived RNA/DNA ratios: results from a metaanalysis. Mar. Ecol. Prog. Ser., 371: 221-232.

Bulow, F.J. - 1970. RNA/DNA ratios as indicators of recent growth rates of a fish. J. Fish. Res. Bd. Can., 27: 2343-2349.

Caldarone, E.M. - 2005. Estimating growth in haddock larvae Melanogrammus aeglefinus from RNA:DNA ratios and water temperature. Mar. Ecol. Prog. Ser., 293:241-252.

Caldarone, E.M., C.M. Clemmesen, E. Berdalet, T.J. Miller, A. Folkvord, G.J. Holt, M.P. Olivar and I.M. Suthers. - 2006. Intercalibration of four spectrofluorometric protocols for measuring RNA/DNA ratios in larval and juvenile fish. Limnol. Oceanogr. Methods, 4: 153-163.

Campana, S.E. - 1996. Year-class strength and growth rate in young Atlantic cod Gadus morhua. Mar. Ecol. Prog. Ser., 135: 2126.

Campana, S.E., K.T. Frank, P.C.F. Hurley, P.A. Koeller, F.H. Page and P.C. Smith. -1989 . Year Survival and abundance of young Atlantic cod (Gadus morhua) and haddock (Melanogrammus aeglefinus) as indicators of year-class strength. Can. J. Fish. Aquatic Sci., 46: 171-182.

Carter, C.G., G.C. Seeto, A. Smart, S. Clarke and R.J. van Barneveld. - 1998. Correlates of growth in farmed juvenile southern bluefin tuna Thunnus maccoyii (Castelnau). Aquaculture, 161: $107-119$

Carter, C.G. and D.F. Houlihan. - 2001. Protein synthesis. In: P. Wright and P. Anderson (eds.), Fish physiology, nitrogen excretion, vol. 20, pp. 31-75. Academic Press, New York.

Clemmesen, C. - 1993. Improvements in the fluorimetric determination of the RNA and DNA content in individual marine fish larvae. Mar. Ecol. Prog. Ser., 100, 177-183.

Costello, M.J., J. Edwards and G.W. Potts. - 1990. The diet of the two-spot goby, Gobiusculus flavescens (Pisces). J. Mar. Biol. Ass. U.K., 70: 329-342.

Ehrenberg, S.Z., S. Hansson and R. Elmgren. - 2005. Sublittoral abundance and food consumption of Baltic gobies. J. Fish Biol., 67: 1083-1093.

Ferron, A. and W.C. Leggett . - 1994. An appraisal of condition measures for marine fish larvae. Adv. Mar. Biol., 30: 217-303.

Folch, J., M. Lees and G.H. Sloane-Stanley. - 1957. A simple method for the isolation and purification of total lipids from animal tissue. J. Biol. Chem., 226: 497-509.

Foster, A.R., .F. Houlihan and S.J. Hall. - 1993. Effects of nutrional regime on correlates of growth rate in juvenile Atlantic cod (Gadus morhua): comparisons of morphological and biochemical measurements. Can. J. Fish. Aquat. Sci., 50: 502-512

Frommel, A.Y. - 2008. Influence of temperature on growth and biochemical-based indicators of growth in juvenile Gobiids of the Baltic Sea. Master thesis, Univ. Southern Denmark.

Groves, T.D.D. - 1970. Body composition changes during growth in young sockeye (Oncorhynchus nerka) in fresh water. In: A.H. Weatherly and H.S. Gill (eds). The Biology of Fish Growth, pp. 104-105. Academic Press, London.

Hjort, J. - 1914. Fluctuations in the great fisheries of northern Europe viewed in the light of biological research. Rapp. Prov. Verb., 20: 1-288.

Hoar, W.S. and D.J. Randall - 1969. Fish Physiology, Volume 1: Excretion, Ionic Regulation and Metabolism, pp. 398-414. Aca- 
demic Press, New York.

Katersky, R.S. and C.G. Carter. - 2007. A preliminary study on growth and protein synthesis of juvenile barramundi, Lates calcarifer at different temperatures. Aquaculture, 267: 157-164.

Keast, A., and J.M. Eadie. - 1985. Growth depensation in year-0 largemouth bass: the influence of diet. T. Am. Fish. Soc., 114: 204-213.

Kondratovics, E. - 1997. Distribution, feeding, and growth parameters of young cod in the eastern Baltic in 1970-1992. In: A. Andrushaitis (ed) Proceedings of the $13^{\text {th }}$ Symposium of the Baltic Marine Biologists, pp. 197-203. Riga.

Kuropat, C., R. Mercaldo-Allen, E. Caldarone, R. Goldberg, B. Phelan and F. Thurnberg. - 2002. Evaluation of RNA concentration as an indicator of growth in young-of-the-year winter flounder Pseudopleuronectes americanus and tautog Tautoga onitis. Mar. Ecol. Prog. Ser., 230: 265-274.

Le Pecq, J.B. and C. Paoletti. - 1966. A new fluorometric method for RNA and DNA determination. Anal. Biochem. 17: 100-107.

Lick, R.R. - 1991. Untersuchungen zu Lebenszyklus (Krebse-Fischemarine Saeuger) und Gefrierresistenz anisakider Nematoden in Nord- und Ostsee. Ber. Inst. Meereskd. CAU, Kiel 218.

Lissåker, M., C. Kvarnemo and O. Svensson. - 2003. Effects of a low oxygen environment on parental effort and filial cannibalism in the male sand goby, Pomatoschistus minutus. Behav. Ecol., 14: 374-381.

Lohmeyer, U. and G. Hempel. - 1977. Winter food of the Baltic herring (Clupea harengus L.). Int. Counc. Explor. Sea C.M., 1977/P: 7, 13 p.

Malloy, K.D. and T.E. Targett. - 1994. The use of RNA:DNA ratios to predict growth limitation of juvenile summer flounder (Paralichtys dentatus) from Delaware and North Carolina estuaries. Mar. Biol., 118: 367-375.

Mathers, E.M., D.F. Houlihan and M.J. Cunningham. - 1992. Nucleic acid concentrations and enzyme activities as correlates of growth rate of the saithe Pollachius virens: growth-rate estimates of open-sea fish. Mar. Biol., 112: 363-369.

McCarthy, I.D., E. Moksness, D.A. Pavlov and D.F. Houlihan. 1999. Effects of water temperature on protein synthesis and protein growth in juvenile Atlantic wolfish (Anarhichas lupus). Can. J. Fish. Aquat. Sci., 56: 231-241.

McLaughlin, R.L., M.M. Ferguson M.M. and D.L.G. Noakes. - 1994. Tissue concentrations of RNA and protein for juvenile brook trout (Salvelinus fontinalis): lagged responses to fluctuations in food availability. Fish Physiol. Biochem., 14(6): 459-469.

Oliver, J.D., G.F. Holeton and K.E. Chua - 1979. Overwinter mortality of fingerling smallmouth bass in relation to size, relative energy stores, and environmental temperature. T. Am. Fish. Soc., 108: 130-136.

Peck, M.A., L.J. Buckley, E.M. Caldarone and D.A. Bengston. 2003. Effects of food consumption and temperature on growth rate and biochemical-based indicators of growth in early juvenile Atlantic cod Gadus morhua and haddock Melanogrammus aeglefinus. Mar. Ecol. Prog. Ser., 251: 233-243.

Petereit, C. - 2004. Experimente zum Temperatureinfluss auf fruehe Entwicklungsstadien des Ostseedorsches Gadus morhua. Diploma thesis, Univ. Kiel.

Pfeiler, E. And A. Luna. - 1984. Changes in biochemical composition and energy utilization during metamorphosis of leptocephalus larvae of the bonefish (Albula). Environ. Biol. Fish, 10: 243-251.

Richard, P., J.P. Bergeron, M. Boulhic, R. Galois and J. Pearson-Le Ruyet. - 1991. Effect of starvation on RNA, DNA and protein content of laboratory-reared larvae and juveniles of Solea solea. Mar. Ecol. Prog. Ser., 72: 69-77.

Shepherd, J.G. and D.H. Cushing. - 1980. A mechanism for density-dependent survival of larval fish as the basis of a stockrecruitment relationship. Journal du Conseil, 39: 160-167.

Sole, M., J. Kopecka and L.M. García de la Parra. - 2006. Seasonal variations of selected biomarkers in sand gobies Pomatoschistus minutus from the Guadalquivir estuary, southwest Spain. Arch. Environ. Contam. Toxicol., 50: 249-255.

Thomas, W.H., H.L. Scotten and J.S. Bradshaw. - 1963. Thermal gradient incubators for small aquatic organisms. Limnol. Oceanogr., 8: 357-360.

Weber, L.P, P.S. Higgins, R.I. Carlson and D.M. Janz. - 2003. Development and validation of methods for measuring multiple biochemical indices of condition in juvenile fishes. J. Fish Biol., 63: 637-658.

Wicker, A.M. and W.E. Johnson. - 1987. Relationships among fat content, condition factor, and first-year survival of Florida largemouth bass. T. Am. Fish. Soc., 116: 264-271.

Received November 14, 2008. Accepted August 24, 2009. Published online October 5, 2009. 